\title{
A Rare Case of Bacterial Dermohypodermitis Associated with Pregnancy Un Cas Rare De Dermohypodermite Bactérienne Associée A La Grossesse
}

Meriem Serraj Andaloussi ${ }^{1 *}$, Oumeyma Baroud ${ }^{1}$, Majda Achbbak ${ }^{1}$, A. Aiassi ${ }^{2}$, Amine Lamrissi ${ }^{1}$, Karima Fichtali ${ }^{1}$, Said Bouhya ${ }^{1}$, I Moussaid $^{2}$, S .El youssoufi ${ }^{2}$, S.Salmi ${ }^{2}$

${ }^{1}$ Maternity Department, HAROUCHI Hospital, Hassan 2 University, Faculty of Medicine and Pharmacy, Casablanca, Morocco

${ }^{2}$ Maternity Reanimation Service, HAROUCHI Hospital, Hassan 2 University, Faculty of Medicine and Pharmacy, Casablanca, Morocco

DOI: $10.36347 /$ sjmcr.2021.v09i01.021

| Received: 10.01.2021 | Accepted: 21.01.2021 | Published: 28.01.2021

*Corresponding author: Meriem Serraj Andaloussi

Abstract

Bacterial dermohypoderma are serious infections during pregnancy. They can put into play the maternal-fetal prognosis. The essential point is to know how to differentiate an acute non-necrotizing bacterial dermohypoderma (erysipelas), which is a frequent disease and generally evolving favorably, from an acute necosing bacterial dermohypoderma, a rare pathology but an absolute medical-surgical emergency.Necrotizing fasciitis is a medicosurgical emergency, requiring urgent resuscitation and plastic surgery advice. Treatment has several components: treatment of shock, antibiotics, early surgical treatment determining the prognosis and effective anticoagulation due to a high risk of thromboembolism. We report a rare case of necrotizing bacterial dermohypoderma in a pregnancy which was presumed at 8 months complicated by in-utero fetal death followed by maternal death.

Keywords: Bacterial dermohypoderma, Pregnancy, (erysipelas), pathology.

Copyright $\odot 2021$ The Author(s): This is an open-access article distributed under the terms of the Creative Commons Attribution 4.0 International License (CC BY-NC 4.0) which permits unrestricted use, distribution, and reproduction in any medium for non-commercial use provided the original author and source are credited.

\section{INTRODUCTION}

Bacterial dermal hypodermitis (DHB) are infections of the dermis and hypodermis most often caused by group A beta hemolytic streptococcus but sometimes can be plurimicrobial [1, 2]. A marked increase in DHB has recently been reported in subSaharan Africa. This change in the epidemiological profile seems to be linked to the association with risk factors such as: lymphedema, post traumatic wounds, intertrigo inter-toe, vascular ulcers, obesity and artificial depigmentation [3-5]. These different risk factors are often present during pregnancy and could explain the occurrence of DHB in this period [6, 7]. The seriousness of the association between DHB and pregnancy is based on mutual exchange of bad practices. Firstly, DHBs increase the risk of obstetric morbidity linked to severe sepsis, multi-organ failure and on the other hand pregnancy can promote the onset of severe necrotizing forms of DHB [8, 9]. The objective of our work is to determine the epidemiological, clinical, para-clinical, therapeutic and evolutionary aspects of DHB, during pregnancy, illustrated by a case of a patient treated in the ELHAROUCHI IBN ROCHD maternity unit in CASABLANCA.

\section{Patient and Observation}

Mrs. SR, aged 18, primigravida nulliparous, with no pathological history, admitted for fetal death in utero on pregnancy presumed at eight months. The admission examination found a patienthemodynamicallystable, fever at $37.8^{\circ} \mathrm{C}$, blood pressure at $120 / 70 \mathrm{mmHg}$, negative proteinuria on urine strips, with the obstetrical examination a patient outside of labor, without externalized bleeding, a uterus relaxed without perception of active fetal movements. On general examination, we noted the presence of dermohypoderma with onset of necrosis of the left lower limb progressing for 7 days. Obstetric ultrasound reveals a non-progressive mono-fetal pregnancy estimated at 34 weeks. Ultrasound of the soft parts of the left thigh found significant thickening with significant edematous infiltration without a welldefined clearly individualizable collection associated with multiple infra-centimetric inguinal lymphadenopathies of infectious appearance. On deep vein and arterial ultrasound of the left lower limb, there was no deep vein thrombosis in the left lower limb with common femoral, superficial, popliteal, anterior tibial, posterior tibial and foot arteries of normal caliber. The resuscitator was there. The plastic surgeons have been advised for a surgical treatment on time. After Citation: Meriem Serraj Andaloussi et al. A Rare Case of Bacterial Dermohypodermitis Associated with Pregnancy Un Cas Rare De Dermohypodermite Bactérienne Associée A La Grossesse. Sch J Med Case Rep, 2021 Jan 9(1): 77-79. 
conditioning, high fetal extraction was performed supplemented by necrosectomy.

The patient stayed in intensive care for septic shock starting from the skin, intubated ventilated under drugs, an additional excision was performed. Considering the delayed awakening, a brain scan was indicated revealing lesions related to anoxia-hypoxia. The patient was tracheotomized on 22nd day of hospitalization. Inflammation markers remained high. Bacteriological samples came back in favor of imipenem-resistant Acinetobacter baumannii. Inflammation markers remained high. Bacteriological samples came back in favor of imipenem-resistant Acinetobacter baumannii. Patient died at 30th days of hospitalization.

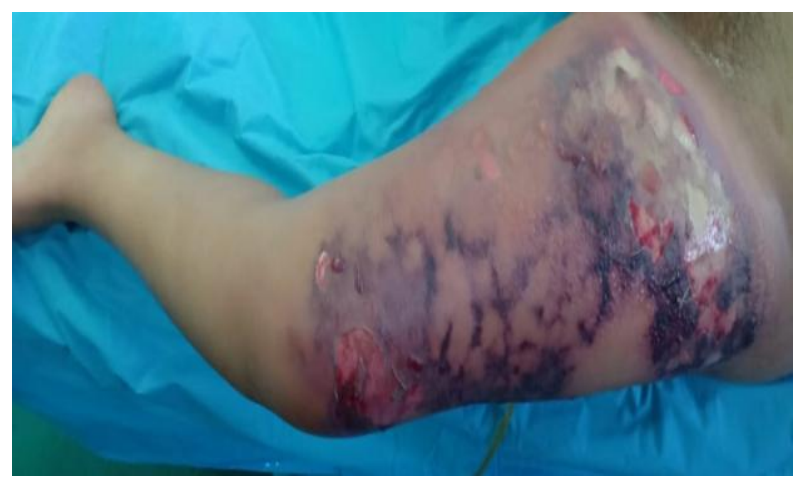

A-Preoeratory aspect

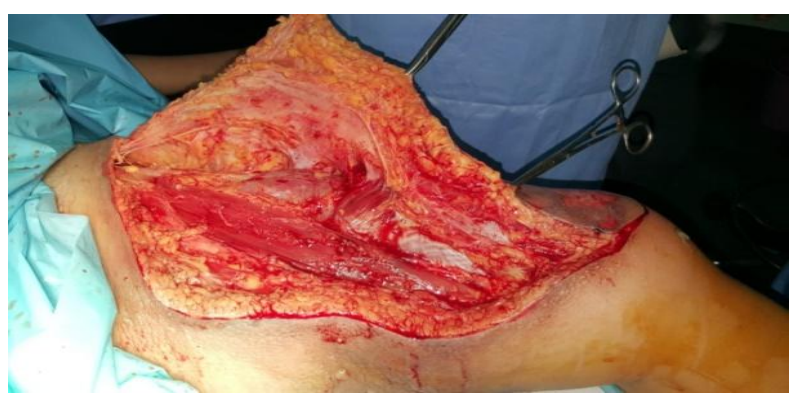

B-Peropperatory aspect

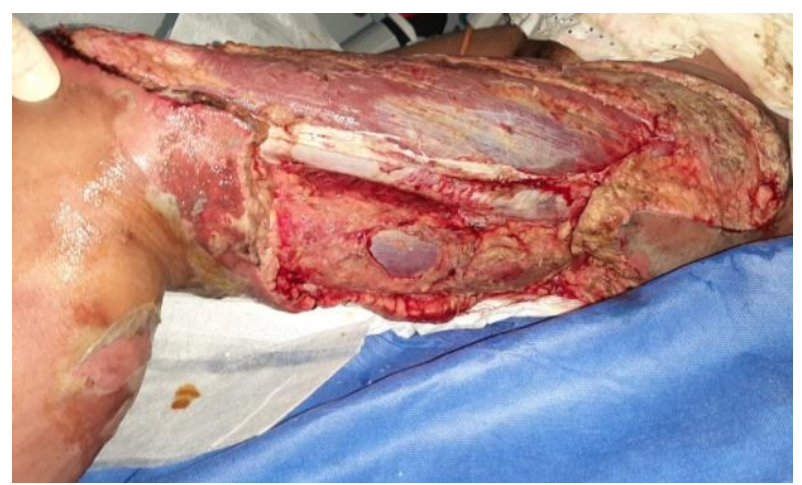

C-Postoperative aspect when changing the dressing

Fig-1:Necrotizing bacterial dermo-hypodermitis

\section{DISCUSSION}

Acute bacterial dermohypoderma can be subdivided into three main forms: the frequent nonnecrotizing bacterial dermohypoderma type streptococcal erysipelas whose treatment is medical, other bacterial dermohypoderma of various microbiology whose management is often medicosurgical and and necrotizing bacterial dermohypodermitis, including necrotizing fasciitis, for which surgical treatment should not be delayed. The main problem is not to ignore, in front of an acute feverish red patch, a necrotizing form from the outset or at risk of becoming so [10]. Our work reports a rarity of DHB during pregnancy, the association with known risk factors for DHB and the severity linked on the one hand by necrotizing DHBs and on the other hand by the occurrence of obstetric complications. A few cases of necrotizing fasciitis have been reported in clinical cases or in small series in the English literature [8,9]. In Africa, these associations are rarely described [6]. Added to this is the lack of knowledge of this pathology by health providers who take care of prenatal consultations in our areas. This lack of knowledge, associated with the use of herbal medicine and the use of non-steroidal anti-inflammatory drugs, could explain the long consultation period in our series. Several risk factors are implicated in the risk of the occurrence of DHB [3, 6]. They are often encountered during pregnancy. Local risk factors such as lymphedema, venous insufficiency, varicose veins can explain the topography of lesions in the lower limbs. Others such as overweight are risk factors for the occurrence of necrotizing fasciitis and are associated with an increased risk of infections during pregnancy according to Magann et al. [11]. Women tend to accelerate depigmentation during pregnancy especially in the second and third trimester, using more aggressive products to be lighter on the day of the child's baptism on the seventh day of birth. Artificial depigmentation is a social phenomenon and has been the subject of numerous studies in Africa [6, 12, 13]. Kebe et al. found that about $50 \%$ of women used cosmetic products intended for depigmenting to look white on the day of their ceremony [14]. These products, mainly based on corticosteroids, cause local immunosuppression and fragility of the skin. Also, Mbengue et al. found that the prolonged application of corticosteroid-based depigmenting products resulted in alteration of the vascular endothelium [15]. In addition, pregnancy represents an additional risk factor due to the alteration of the immune system during the second, third trimester and postpartum period $[12,16]$. Maternal repercussions such as recurrence of DHB could be linked to the lack of control of risk factors, particularly lymphedema. The consequences on the child resulting in either neonatal infection, retention of dead eggs or abortion could be multifactorial [2]. The syndrome infectious, found in $46 \%$ in our series, is a determining factor in the occurrence of obstetric complications. 


\section{CONCLUSION}

Bacterial dermohypoderma are serious infections during pregnancy. They can jeopardize the maternal-fetal prognosis because of their severity and their obstetric complications. Early management and multidisciplinary follow-up could reduce the complications of these bacterial infections during pregnancy.

\section{REFERENCES}

1. Société Française de Dermatologie, Érysipèle et fasciite nécrosante: prise en charge. Conférence de consensus. 2000. Méd Mal Infect. 2000; 30 Supp14: 245- 246.

2. Diousse P, Diatta BA, Thiam M, Toure K, Berthe A, Dione H, Bammo M, Gueye L, Fatou SE, Gueye N, Cisse ML. Les dermohypodermites bactériennes associées à la grossesse: à propos de 43 cas. Revue Africaine de Médecine Interne. 2017 Jun 30;4(12):10-2.

3. Dupuy A, Benchikhi H, Roujeau JC, Bernard P, Vaillant L, Chosidow O, Sassolas B, Guillaume JC, Grob JJ, Bastuji-Garin S. Risk factors for erysipelas of the leg (cellulitis): case-control study. Bmj. 1999 Jun 12;318(7198):1591-4.

4. Mokni M, Dupuy A, Denguezli M, Dhaoui R, Bouassida S, Amri M, Fenniche S, Zeglaoui F, Doss N, Nouira R, Osman-Dhahri AB. Risk factors for erysipelas of the leg in Tunisia: a multicenter case-control study. Dermatology. 2006;212(2):10812.

5. Celestin R, Brown J, Kihiczak G, Schwartz R.A. Erysipelas: a commonpotentially dangerous infection. ActaDermatovenerolAlpPanonicaAdriat. 2007;16(3):123-127.

6. Pereira de Godoy JM, GalaciniMassari P, Yoshino Rosinha M, MarinelliBrandao R, Foroni Casas AL. Epidemiological Data and Comorbidities of 428Patients Hospitalized With Erysipelas. Angiology. 2012; 61(5): 492-494.

7. Pitché P, Diatta B, Faye O, Diané BF, Sangaré A, Niamba P, Mandengue C, Kobengue L, Saka B, Diop A, Ly F. Facteurs de risque associé à l'érysipèle de jambe en Afrique subsaharienne: étude multicentrique cas-témoins. InAnnales de Dermatologie et de Vénéréologie. 2015 142(11): 633-638). Elsevier Masson.

8. Diedhiou $\mathrm{D}$, Lèye MM, Touré $\mathrm{M}$, Boiro $\mathrm{D}$, Sow $\mathrm{D}$, Lèye YM. Dermohypodermites bactériennes à
Dakar: étude rétrospective de 194 cassuivis en médecine interne à la clinique médicale II. Rev. Cames Santé. 2013;1(1): 31-35.

9. Nikolaou M, Zampakis P, Vervita V, Almaloglou $\mathrm{K}$, Adonakis G, Marangos M, Decavalas G. Necrotizing fasciitis complicating pregnancy: a case report and literature review. Case reports in obstetrics and gynecology. 2014 Jan 1;2014.

10. Gallup DG, Freedman MA, Meguiar RV, Freedman SN, Nolan TE. "Necrotizingfasciitis in gynecologic and obstetric patients: a surgical emergency," AmericanJournal of Obstetrics and Gynecology. 2002; 187(2): 305-311.

11. Erysipèle BE. dermohypodermites bactériennes et fasciites nécrosantes. EMC Dermatol. 2013;8(2):10 .

12. Magann EF, Doherty DA, Sandlin AT, Chauhan SP, Morrison JC. The effects of an increasing gradient of maternal obesity on pregnancy outcomes. Australian and New Zealand Journal of Obstetrics and Gynaecology. 2013 Jun;53(3):2507.

13. SH SG. Cobin RH. el-Harazy E. Wallenstein S. Davies TF. A prospective study of lymphocyteinitiated immunosuppression in normal pregnancy: evidence of a T-cell etiology for postpartum thyroid dysfunction. J Clin Endocrinol Metab. 1992;74:645-53.

14. Dioussé P, Ndiaye M, Dione H, Bammo M, Sow O, Seck F, Gueye N, Diop A, Diatta BA, Dieng MT, Diop BM. Bacterial dermohypodermitis at the Thies Regional Hospital, Senegal (West Africa): A retrospective study of 425 cases. Our Dermatology Online. 2017 Jul 1;8(3):233.

15. Kebe M, Yahya S, Lo B, Ball M. Etude des complications de la dépigmentationartificielle à Nouakchott, Mauritanie. Mali Medical. 2015;3(1):38-40

16. Mbengue A, Diaw M, Akpo G, Deme H, Ouedraogo V, Sow AK. Evaluation ofvascular function in depigmentedblack women: Comparative study. National Journal of Physiology, Pharmacy and Pharmacology. 2017;7(4):420-424.

17. Krause PJ, Ingardia CJ, Pontius LT, Malech HL, LoBello TM, Maderazo EG. Host defense during pregnancy: neutrophil chemotaxis and adherence. American Journal of Obstetrics and Gynecology. 1987; 157(2): 274-280. 